\title{
Foundation evaluation of a barrage using geophysical and geotechnical investigations
}

\author{
B Butchi Babu, PC Jha, S Nelliat and YV Sivaram \\ National Institute of Rock Mechanics \\ Bengaluru, India \\ bbabugeo@gmail.com
}

\begin{abstract}
Geophysical investigations prior to constructions stage are often met with difficult site conditions particularly over shallow water bodies. Due to site constraints, standard data acquisition procedures, either onshore or offshore may not be suitable in such cases. In this situation designing of site specific investigation technique becomes necessary to explore the subsurface condition. In one such case study for locating the barrage axis with rockmass in the foundation, seismic refraction survey was deployed. The survey data was acquired both onland and onwater-body to map the bed rock depth and geological features in the study area. A combined section was then obtained by joining lines on surface and over waterbody.Based on data processing, the subsurface layers wereclassified as compact soil, weathered rockmass layer with boulders, jointed rockmass layer and hard rock layer based on the seismic velocity range. These results were correlated with the available data on geological situation, Standard Penetration Test (SPT) values and laboratory studies. Interpretation of survey data hinted at the shifting of river course away from the left bank by at least by $50-60 \mathrm{~m}$. Considering the site conditions, it was suggested that the left bank abutment may be extended by $30 \mathrm{~m}$ for coupling with the in-situ hard rock.
\end{abstract}

Keywords-Foundation evaluation; seismic refraction; Standard Penetration test.

\section{I.INTRODUCTION}

The Nekkiladi Small Hydal Project (NSHP) is proposed at the confluence of Kumaradhara and Netravati rivers in the Dakshina Kannadadistrict Karnataka. This project envisages flows of Kumaradhara river byconstruction of a diversion barrage across the river with a gross head of $7.3 \mathrm{~m}$ for generating $12.5 \mathrm{MW}$ of power. The proposed barrage for this NSHP project is $7 \mathrm{~m}$ in height located approximately $600 \mathrm{~m}$ upstream of existing Puttur barrage, which was constructed for the drinking water supply to Puttur village. As per design layout, a canal draws water from the reservoir, conduits to the powerhouse on the right bank and the tail water is discharged back to the river through a short channel. Based on rock exposures on the right bank at powerhouse locations and the results of some borehole data, barrage axis location was decided. The alignment of the barrage axis was chosen expecting that the foundation and abutments would be on sound rock. The excavation along this barrage axis progressed from the right bank and foundation was laid. But when the excavation progressed beyond $30 \mathrm{~m}$ length from the right bank, sandy soil and boulders were encountered in the foundation instead of hard rock. This led to the abandoning of the barrage axis and necessitated a proper scientific evaluation of the actual foundation conditions along this alignment.

For the assessment of the subsurface conditions along the proposed barrage axis and suggesting alternative locations for the same, comprehensive geophysical and geotechnical investigations were undertaken.Based on the correlation of field data with lithology and drilling data, earlier barrage axis was ruled out and new location was suggested for laying the foundation of the barrage.In this paper we describe the detailed field investigations carried out for this purpose.

\section{II.LOCATION AND GEOLOGY OF THE STUDY AREA}

Geologically, the Nethravati and Kumaradhararivers fall in the metamorphic transition zone of the West Dharwar Craton composed of granodioritic gneissic complex of Archean age [1]. This metamorphic transition zone separates the Dharwar Craton in two parts as Plateau (southern) and Western Ghats (northern).

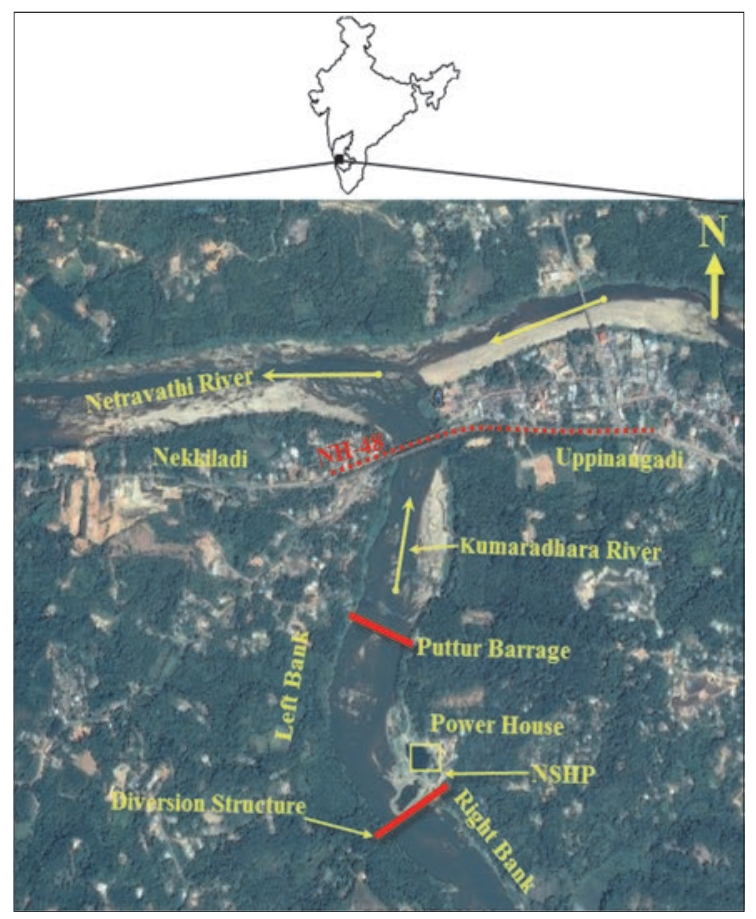

Fig.1: Location map of NSHP showing proposed diversion structure and powerhouse. 
The Nethravati River drains on both sides of the metamorphic transition zone encompassing major lithologiesincluding meta-sediments, banded iron formations, amphibolitic facies, gneisses, and foliated charnockites whereas Kumaradhara River course is controlled by hard rock formations of granite, charnokites, laterites etc [2]. Charnokite and laterites are spread on the both the banks of study area. Exposed Charnokitewas observed on the river bed, right bank and Laterite, Charnokite outcrops were noticed even $100 \mathrm{~m}$ away from the left bank. Location of the study area is around $300 \mathrm{~km}$ from Bangalore city close to Uppinangadi town on NH-48 connecting Bangalore Mangalore (Fig.1).

The existing Puttur barrage meant for drinking water supply is about $600 \mathrm{~m}$ downstream of the proposed diversion structure (barrage) of Nekkiladi project. Waterout-flow from the Nekkiladi project will be restored back in the river upstream of the Puttur barrage.

\section{III.METHODS AND DATA ACQUISITION}

The combined approach of geophysical and geotechnical investigations is conventionally used to solve construction stage problems $[3,4,5,6,7]$. Earlier works refer to extensive use of geophysical methods in the foundation evaluation [8, 9]. Seismic refraction survey is the commonly used surface geophysical technique to determine depthtobedrock, competence of bedrock, depth to the water table, or depth to other seismic velocity boundaries $[10,11,12]$. Seismic refraction was used to study the rock properties, rock quality and mapping of tectonically disturbed zones at various $\mathrm{dam} /$ barrage sites in India $[13,14,15,16]$. Similarly geotechnical investigations using Standard Penetration Test (SPT) were used regularly carried out to understand the soil stratification and layer thickness for estimating the geological and hydrological conditions [17]. SPT N-value is used as an indispensible index for the structural design and its correlation with shear wave velocity and shear modulus is widely used for site response and liquefaction analysis [18]. In absence of direct shear wave measurements, site-specific correlation wasused for converting SPT N-value into shear wave velocity[19].

Based on these standard works, it was decided to carry out seismic refraction survey in the present investigation.The location of the barrage axis is under water most of the times including summer due to pondage of water at Puttur barrage. This site constraint restricted the used of a standard lay-out for this technique.The array for seismic refraction survey was designed accordingly by using hydrophone chain spread acrossthe river segment. Since the length of hydrophone chain was not sufficient to cover the entire stretch of river in one go, the alignment over water was covered in seven segments. Explosives were used as seismic sources for survey on the water body. Standard surface seismic refraction survey was carried on the extension of this alignment on both the abutments. Similarly two survey lines were planned across the river to estimate lateral trend of the bedrock profile below the water level. Overall plan of geophysical survey is shown in fig. 2 .

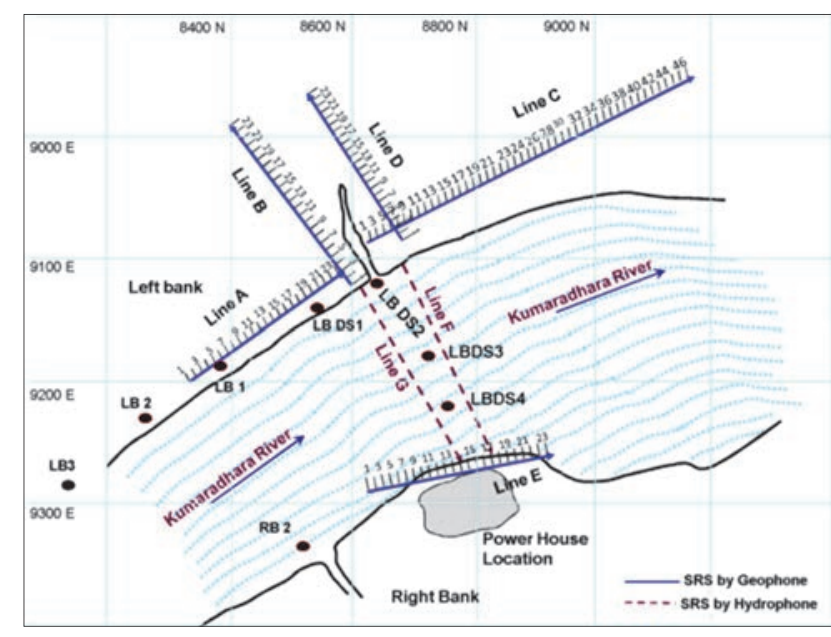

Fig.2 Seismic refraction survey lines (Line A to Line G) across the river and on both the banks.

\section{A. Seismic Refraction Survey}

Two alternate barrage axes were explored across the river by using seismic refraction survey. Seismic refraction data acquisition was done both on left and right abutments along the extension of these two axes as well along some lateral lines. All surveys were done using 24 channel signal enhancement seismograph. For surface survey, geophone spacing was maintained at $5 \mathrm{~m}$ interval for the line length of $115 \mathrm{~m}$ and sledge-hammer was used as source. Five lines were acquired on the left bank including two lateral lines (Line B\&D) and one line on the right bank. Seven to nine shots were gathered for each of the profile line to increase the data density. High $\mathrm{S} / \mathrm{N}$ ratio was ensured for each of the seismic trace by stacking of hammer blows at different shot locations.

For survey across the river, 12-channel hydrophone chain with $2 \mathrm{~m}$ separation was used as receiver and explosives were used as source. River bottom profiling was carried out across the river width of $156 \mathrm{~m}$ (left bank to right bank) to estimate the water column thickness. The average variation of water depth from left bank to right bank is $2.5 \mathrm{~m}$ (except $40 \mathrm{~m}$ portion towards left bank where water depth is around 5-6m). Arrangements were made to stretch hydrophone chain along alignment and to keep sensors at the same depth. This was achieved by tying the rope on both the banks and hanging the hydrophone chain from the rope at constant depth of $2 \mathrm{~m}$ (Fig.3).After gathering data for six shot locations [three forward shots $(-5 \mathrm{~m}, 15 \mathrm{~m},-25 \mathrm{~m}$ on left bank) and three reverse shots $(+5 \mathrm{~m},+15 \mathrm{~m},+25 \mathrm{~m}$ on right bank)], this hydrophone-chain setup was moved from left bank to right bank.In total, seven shifts were made to reach from left bank to right bank for one river-axis line. Seismograph with supporting data acquisition set-up was kept inside the small boat for recording the data. This way two river-lines (Line F and Line $G$ ) were surveyed with high signal to noise ratio. Since there was virtually no to minimal flow of water due to Puttur barrage ahead on the downstream, the water level in the river was steady leading to a minimum noise level (except rope movement due to wind). 


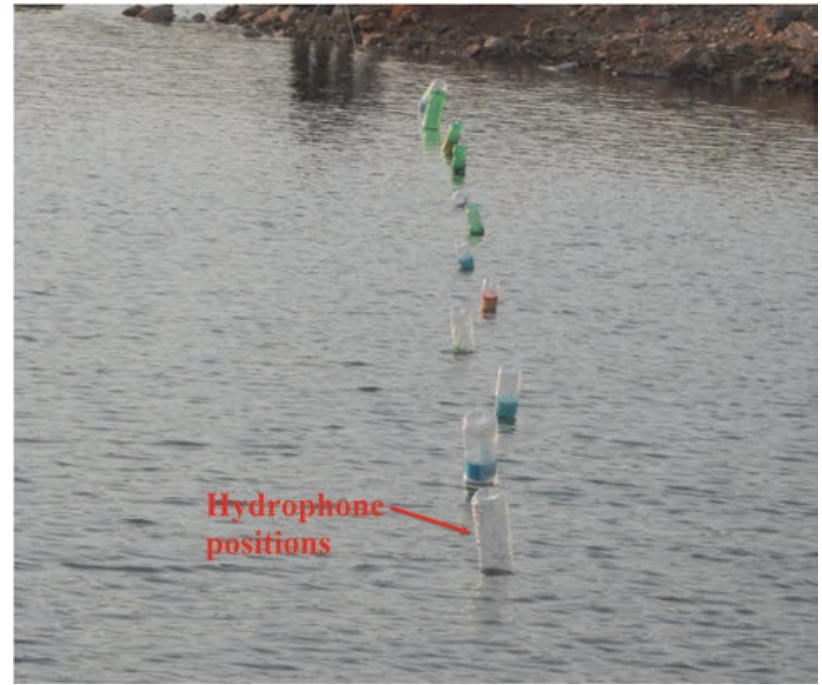

Fig.3 Schematic lay-out of the seismic refraction survey on the water-body (river), half filled water bottles tied at sensors locations (hydrophones) kept it afloat at the same depth level.

\section{B. Standard Penetration Test (SPT) and Lithology}

SPT tests were conducted as per procedure IS:2131 to determine penetration resistance. Split spoon sampler was used with outer inner diaof $50.8 \mathrm{~mm}$ and $35 \mathrm{~mm}$ respectively. Free fall height of $75 \mathrm{~cm}$ with drop weight of $63.5 \mathrm{~kg}$ was used for penetration of the probe. The length of the sampler was $60 \mathrm{~cm}$. The SPT blow counts were conducted at regular intervals of $1.5 \mathrm{~m} /$ change in strata in the boreholes. The recorded blow counts were corrected for overburden and dilatancy to obtain the corrected SPT N values.

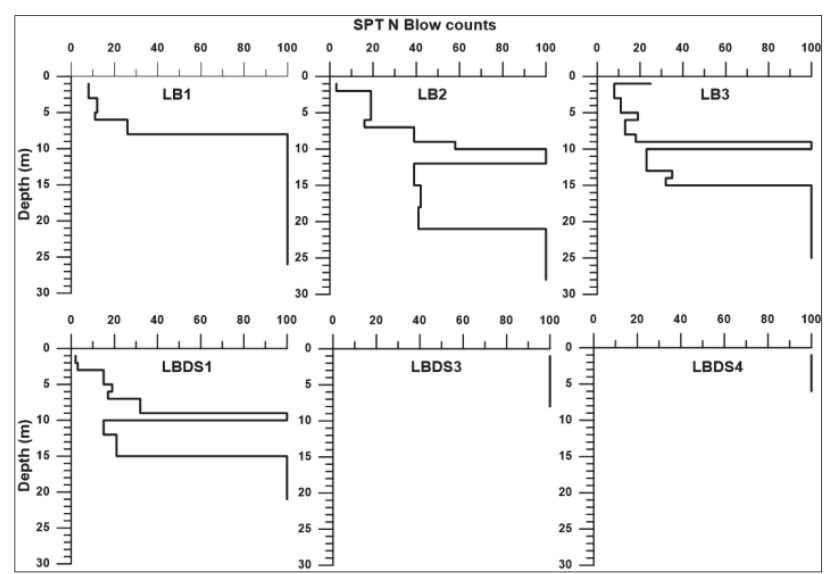

Fig.4 Variation of SPT N value with depth for six boreholes.

The SPT N values so obtained were plotted against depth as shown in fig.4.During the SPT boring time, the disturbed and undisturbed samples were collected for each borehole and preserved for better understanding of the subsurface. The core samples were mapped and plotted against depth as shown in fig.5. Lithological data of four boreholes can be classified as two categories. Category-1 comprising LB1 and LBDS1 shows similar layer boundaries of clay silt/sand layer of $8-9 \mathrm{~m}$ followed by disintegrated weathered rock layer up to $15 \mathrm{~m}$ depth. Weathered rock was mapped up to $25 \mathrm{~m}$ depth followed by medium hard rock. Category- 2 comprising
LBDS4 and RB2 showsilty sand layer with boulder up to $5 \mathrm{~m}$ depth followed by hard rock.

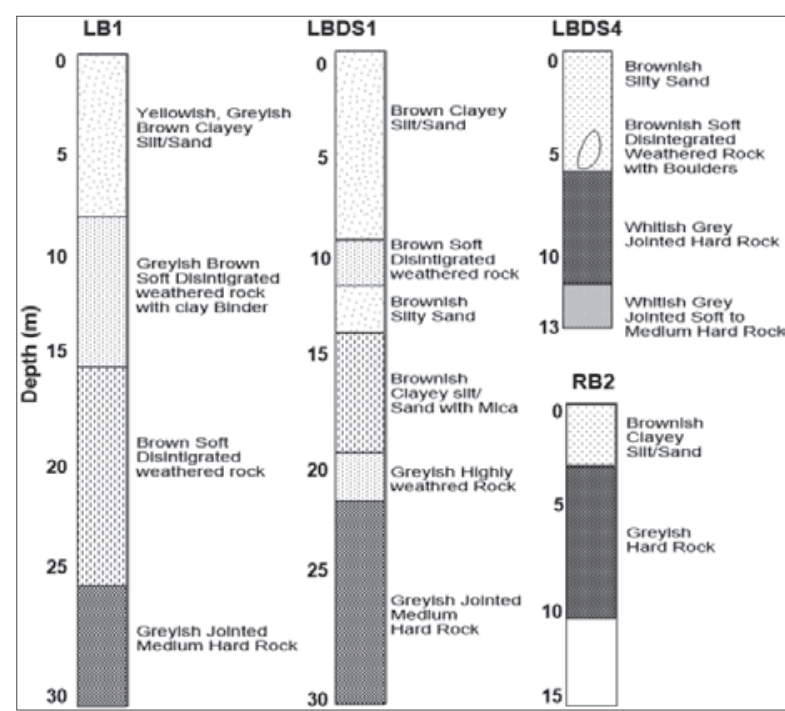

Fig. 5 Lithological boundaries for the four boreholes

\section{Laboratory Test of Compressive strength}

Compressive strength of selected core rock samples as per IS:9143 was determinedto assess their physical and engineering properties. Compressive strength of some of some of the rock samples are reproduced in Table- 1 .

TABLE.I COMPRESSIVE STRENGTH OF ROCK SAMPLES

\begin{tabular}{|c|c|c|c|c|c|c|}
\hline $\begin{array}{c}\text { Boreho } \\
\text { le No. }\end{array}$ & $\begin{array}{c}\text { Drill } \\
\text { Rum } \\
(\mathbf{m})\end{array}$ & $\begin{array}{c}\text { CR( } \\
\mathbf{\%})\end{array}$ & $\begin{array}{c}\text { RQ } \\
\mathbf{D} \\
\mathbf{( \% )}\end{array}$ & $\begin{array}{c}\text { Densi } \\
\mathbf{t y} \\
\mathbf{( g / c c})\end{array}$ & $\begin{array}{c}\text { Load } \\
(\mathbf{K N})\end{array}$ & $\begin{array}{c}\text { Comp. } \\
\text { Strengt } \\
\mathbf{h} \\
\mathbf{( K g / c m} \\
\mathbf{2}\end{array}$ \\
\hline \multirow{2}{*}{ LBDS2 } & $4.0-5.0$ & 51 & 41 & 2.81 & 130 & 567.92 \\
\cline { 2 - 7 } & $5.6-6.6$ & 64 & 58 & 2.79 & 142 & 620.34 \\
\hline LBDS3 & $9.0-10$ & 58 & 58 & 2.73 & 124 & 541.71 \\
\hline \multirow{2}{*}{ LBDS4 } & $5.5-6.8$ & 98 & 69 & 2.75 & 120 & 524.23 \\
\cline { 2 - 7 } & $8.4-9.4$ & 95 & 35 & 2.73 & 120 & 524.23 \\
\hline
\end{tabular}

\section{IV.INTERPRETATION OF RESULTS AND DISCUSSION}

Seismic velocity sections of the study area are obtained for the four layer scenario comprising water-body $(1500 \mathrm{~m} / \mathrm{s})$, weathered rock layer $(1500-2500 \mathrm{~m} / \mathrm{s})$, jointed rockmass layer $(2500-3500 \mathrm{~m} / \mathrm{s})$ and hard rock $(\geq 3500 \mathrm{~m} / \mathrm{s})$.

Out of seven seismic refraction survey lines, two lines (Line $F$ and $G$ ) surveyed across the river with a separation of $30 \mathrm{~m}$ are of prime importance. The bed rock level and nature of rockmass condition along these two lines will assist inchoosing the best possible alignment.

For better understanding the subsurface below the river, seismic velocity section along line-F is projected towards the left bank by combining the section along line-D which is running along the same direction but with $5-10 \mathrm{~m}$ offset towards downstream of line-F Similarly the seismic velocity section along line- $G$ is projected towards the left bank by combining the section along line-B which is running along the same direction without any offset.They are shown in (Fig.6, top \& bottom). 


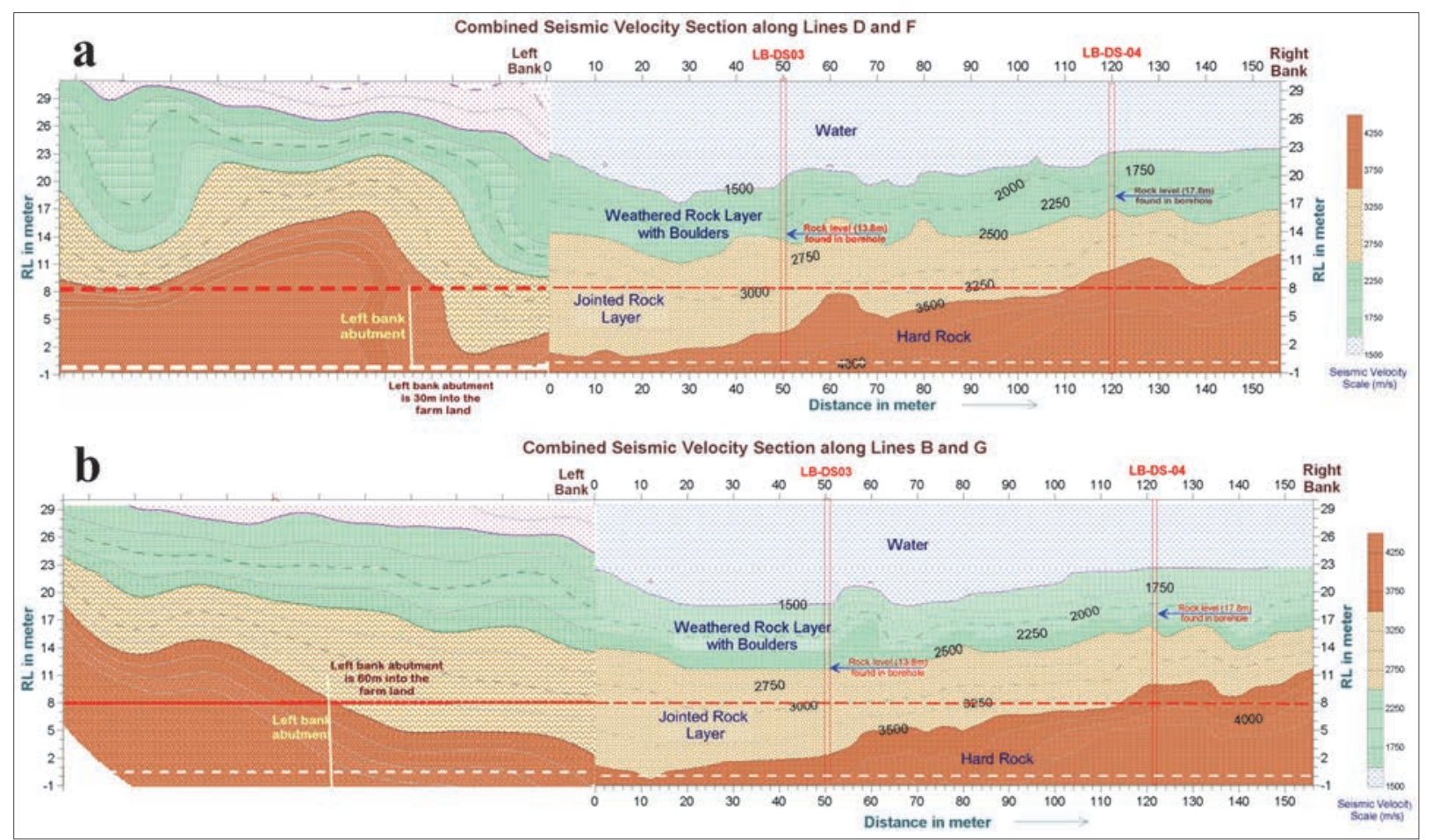

Fig.6 The combined seismic wave velocity sections along the two barrages axes (a) combined section of Line D and F (b) Combined section of Line B and G.

As far as foundation of the barrage is concerned, it is not necessary to insist upon hard rock foundation for $7 \mathrm{~m}$ high barrage. The central portion can be laid on the jointed rock and the bottom upto the hard rock level can be grouted to contain the permeability within the permissible limit. Along both the alignments $6 \mathrm{a}$ and $6 \mathrm{~b}$ competent hard rock or jointed rock level is mapped at $\mathrm{RL}=8 \mathrm{~m}$, as shown by red coloured dashed lines. Thus it is possible to choose barrage axis along any of the two lines with a founding depth below $\mathrm{RL}=8 \mathrm{~m}$. But if the designer feels that hard rock foundation is essential, then founding depth at $\mathrm{RL}=0 \mathrm{~m}$, as indicated by the white-coloured dashed line, has to be chosen which of course will be a costly proposition.

The major difference in the choice of two barrage axis lines is in the extent of the left axis abutment. The abutment extension on the left bank is $30 \mathrm{~m}$ along line- $\mathrm{F}$ (fig 6a) and $60 \mathrm{~m}$ along line- $\mathrm{G}($ fig $6 \mathrm{~b})$.Thus preferring the alignment along line-G (fig 6b) will add more cost to the project not only in terms of construction but even in acquiring additional farm land and submergence area. Thus on comparison, it is obvious that construction of barrage axis along line-F is more economical and stable (due to presence of steep hard rock profile at the left abutment) from design point of view.

Therefore, the foundation of the diversion structure (barrage) with jointed rock in the centre and abutments on the hard rock along line-F is the best possible option. In this case, it is possible even to choose a shallower foundation level at $R L=10-12 \mathrm{~m}$, which was originally planned along the failed barrage axis.

\section{V.CONCLUSION}

Going by the interpretations of the various subsurface sections and discussions of results, the following conclusion may be drawn :

- Considering the small diversion structure $(7 \mathrm{~m}$ high barrage), the founding level at $\mathrm{RL}=8-10 \mathrm{~m}$ on a permeable foundation seems alright. Of the two alternate axes surveyed across the river, line-F appears to be better choice in view of logistic consideration of lesser land acquisition cost and a lesser abutment penetration on the left bank side.

- The central portion of the barrage which is on the jointed rock mass layer should be grouted till the hard rock level. This involves grouting upto a depth of $5-7 \mathrm{~m}$. Abutment on left bank should extend to ensure its coupling with the hard rock.

- The trend of hard rock layer from left bank to right bank reveals that the Hard Rock level on the right bank matches with the left bank after some $30-50 \mathrm{~m}$ inside the farm land. This hints at possible shifting of the river course away from the left bank. This was evidenced even by the ground topography and presence of riverborne material some 60-70 away on the left bank side. Thus, in all probability, the river course has shifted towards the right by at least by $50-60 \mathrm{~m}$ at the proposed barrage location. The absence of hard rock in the barrage foundation at the originally proposed (failed) axis may be the result of this river shifting over a shortdistance. 


\section{REFERENCES}

[1] Gurumurthy G.P., Balakrishna K., Riotte J., Braun J.J., Audry S., Shankar H.N. U., and Manjunatha B.R. Controls on intense silicate weathering in a tropical river, southwestern India, Chemical Geology 300-301, pp. 61-69, 2012.

[2] Umeshchandra H.G., and Vijay Kumar V.C. Morphometric Analysis of Kumaradhara River Basin, Dakshina Kannada, Karnataka, Imperial Journal of Interdisciplinary Research,Vol-2, Issue-7, p.1370, 2016.

[3] Pitilakis K., Raptakis D., Lontzetidis K T., Vassilikou T. and JongmansD. Geotechnical and geophysical description of EuroScantests, using field and laboratory tests and moderate strong ground motions.Journal of Earthquake Engineering, 3,381-409, 1999.

[4] Donohue S., Gavin K., and Tolooiyan A. Geophysical and geotechnical assessment of railway embarkment failure. Near Surface Geophysics, 9(1),33-44, 2011.

[5] Oyedele K.F., Oladele S., and Adedoyin O. Application of Geophysical and Geotechnical Methods to Site Characterization for ConstructionPurposes at Ikoyi, Lagos, Nigeria. Journal of Earth Sciences and Geotechnical Engineering, vol.1, no.1, 87-100, 2011.

[6] Ozcep F.and Ozcep T. Geophysical analysis of the soils for civil (Geotechnical) engineering and urban planning purposes: some case histories from Turkey. International Journal of Physical Sciences, 6(5), 1169-1195, 2011.

[7] Jamiolkowski M. Role of geophysical testing in geotechnical site characterization. Soils and Rocks, Sao Paulo, 35(2), 1-21, 2012.

[8] Keceli A. Soil parameters which can be determined with seismic velocities, Jeofizik, 16, 17-29, 2012.

[9] Sully J.P., and Campanella R.G. Evaluation of in situ anisotropy from crosshole and down hole shear wave velocities measurements. Geotechnique, 45(2), 267-282, 1995.

[10] Cummings D. Determination of depths to an Irregular interface in shallow seismic refraction surveys using a pocket calculator, GEOPHYSICS, VOL. 44, NO. 12, 1987-1998, 1979.

[11] Redpath B.B . Seismic refraction exploration for engineering site investigations, Technical report E-73-4, National Technical information services U.S., SpringfieldVA.USA. 1973.

[12] Sjogren, B.O. and Sandberg, J. Seismic classification of rock mass qualities, Geophys. Prospecting, 27, 409-442, 1979.

[13] Savich A.I., Mikhailov A.D., Koptev V.I. and Ijin M.M. Geophysical studies of rock mass, A 19 - A 30, International society of Rock Mechanics, Melbourne, Australia, 1983.

[14] Sudhindra C., Dhawan A.K., Brar S.S., Gangadhar R.B. and Mikhailov A.D. Geophysical investigation of Tehri Dam Project, National symposium, Application of Rock Mechanics in RiverValley projects, Roorkee, India, 1989.

[15] Verghese A., Krishnaiah C., Brar S.S., Dhawan A.K. and Petrov A. Geophysical investigation of stilling basin area of Tehri dam project, published in proceedings of 56 th R\&D session of CBIP, Hyderabad, India, 1991

[16] Ramteke R.S., Krishnaiah C., Deshpande V.C. and Shirke J.M. Foundation Investigations for a barrage at Lata-Tapovan, Uttaranchal by Geophysical survey, presented in Indian Geotechnical Conference, Chennai, India, 2006.

[17] Terzaghi K. and Peck R. B. Soil mechanics in engineering practice, 2nd edition, John Wiley \& Sons Publication, New York, 1967.

[18] Seed H. B., Wong R T., Idriss I M and Tokimatsu K. Modulai and damping factors for dynamic analysis of cohesionless soils, Journal of Geotechnical Engineering, 112 (1), 1016-1032, 1986.

[19] T. Imai and K.Tonouchi Corrolation N-value with S-wave velocity and shear modulus. Proceedings of 2nd European Symposium on Penetration testing, 67-72, 1982 